\title{
MEN WHO \\ SIT IN \\ CHAIRS \\ UNDER TREES
}

Peter Israel

I USED TO see him below when I crossed the little bridge-twice each day at least.

He sat mostly under the olive trees near the stream. He wore a straw hat, a white shirt, a pair of gray trousers. His arms rested on the arms of his chair. He might have been fishing except that his hands didn't hold a rod and the stream was dry more often than not.

He looked big from the bridge. I used to think he was just a big old man who'd nothing better to do than sit under an olive tree and watch the other trees growing up the far slope. For all I knew he slept in the chair, though I supposed he had somewhere to go at night and to eat or when it rained.

I felt like going down to see him one warm spring evening and I did. The sun was setting very slowly, I remember. I think there were a few clouds in the sky but they weren't in any hurry either when I climbed down the far side of the stream where the descent is easier. The streambed had some water in it that year but you could pick your way across on stones without getting your feet wet.

He was sitting in the chair under the olive tree looking across the stream in my direction. The hat almost covered his eyes. If he saw me, he gave no indication of it, not even when I was close enough to say "Hello" without shouting.

He wasn't as big as I'd thought. Just about any man would've filled the wicker chair. Maybe it's only that bodies look bigger when they sit a long while in much the same posture. You didn't see angles first off when you looked at him, you saw a mass in a chair. Only when he talked or stood up did you see the angles.

His straw hat looked as if it'd been worn a lot. The shirt and trousers were wrinkled but clean. Sometimes he went barefoot and sometimes he wore shoes without socks. I think he had the shoes on that time.

He didn't answer my first hello or my second and I could only assume he saw me because his eyes were open under the hat and looking in my direction. But as I lowered to the ground beside him, picking a stretch of root as my seat, he shifted a little in his chair, making that peculiar noise and motion people make when they give you room without actually moving.

Something-the setting sun perhaps-discouraged conversation. I didn't say 
anything and he didn't either. We sat side by side, he in the wicker chair and I on my root, disturbing neither each other nor the peace. For it was peaceful under the tree, I felt it right away. Not extraordinarily or supernaturally so, just peaceful. It was a peaceful place. It pleased me to stay there and I did and only when it threatened to be too dark for me to find my way up the slope did I budge.

I stretched my bones and was about to say something-"Goodby" maybe or simply "Good night"-when I saw in the dim light that his head had tilted forward. His eyes were closed.

When I awoke the next morning I wasn't aware of having dreamed, only of the soundness of the sleep. It was early, very early, yet I was wide awake. I washed, shaved, drank some cold coffee, began to dress.

I guess I must've known then that I'd be going back, for I went no further than shirt and trousers. I left the rest of it as it lay.

When I reached the bridge I saw him in his chair under the olive tree and I climbed down the near bank to the stream.

It was so early the sun had scarcely risen but he sat in the same posture, studying the slope. I got a good look then at the face I would know better than my own. His skin had deep grooves. The principal two started near the bridge of his nose and curved down to the edges of his mouth. Minor ones ran alongside and others across the forehead and some started out from the corners of his eyes. The brows seemed forced downward. He had a shock of white and black hair which you didn't often see because of the hat. And full lips and the black eyes which seldom blinked but with that tense look about them as if he was concentrating hard.

I sat on my root, letting the sun warm me, and in a little while he said:

"You might like to try some of this. It's pretty good."

He reached on the other side of his chair and picked up a pail and put it on the ground next to me. The pail was filled almost to the brim with food-wrapped in cloth, in bowls and plastic containers, in aluminum foil, in jars. There was fried chicken and whole tomatoes, potato salad, fruit, bread, I forget what all else. A thermosful of coffee, with a second cup.

I didn't eat any till later in the day but it was good. And more than enough for two much less one, and he'd already had his. He ate mostly at sunrise though sometimes he took a bite toward mid-afternoon. And drank coffee off and on through the day, as I did, hot or cold, it didn't matter.

His wife had prepared it.

No.

Yes, it was still his wife then. Later it was the women on the slopes, some of them, and days when there was nothing, but then it was still his wife. Sometimes she brought it herself but usually she sent one of his boys.

I spent only one more night in my own house, the next one. I've hardly been back since. As far as I know the door is still open the way I left it.

The next morning the second wicker chair was waiting for me next to his along with other provisions. I had a blanket, one at first and then a second, and 
pipe tobacco regularly with the food pail. Once or twice I went home for other items.

I had adjustments to make, oh yes, and some of them arduous. I had to learn to sleep sitting up or, as I did particularly in the beginning, on the bare ground. I'd never been comfortable sleeping outdoors and it took me many nights to learn to enjoy it. I had to endure all the changes of weather such as are experienced by men sitting under olive trees, and though our winters are more like most people's springs, it's tough to this day for me to sit for hours when there's no sun to be seen, no birds to be heard, only rain dripping and clouds around the hilltops.

I had to learn to eat less, and less often. Silly as it sounds, I even had to learn to relieve myself outdoors without being embarrassed. And of course I had to learn to sit in the company of a man who sometimes said nothing for hours on end.

It's funny. When I was growing up the worst words I knew were "peace and quiet." All someone had to do to set my teeth on edge was say them. I couldn't sit still. I was always doing something, and when I did fall asleep at night it was from exhaustion. But there comes a time for some men when their lives become just humdrum and not worth the fuss. All they want is for time to slow down. Most are too caught up to do anything about it except dream. Me too. Except that I met a man who helped me.

But I'm talking too much of myself.

Occupational hazard.

The facts of his past are known. I can add little to them. Mr. Charles was born not so far from here. He was an excellent student, even brilliant. He went off to a university and then into the army. Once when I asked him about the army he told me I asked too many questions.

In an intellectual sense though, he hated the military, the same way he hated nations and patriots and isms and all the hypocrisies of the big powers which run the world. Yet he had fought in a war. He thought he had once killed an enemy. He wasn't sure. He didn't like to be reminded of it.

After the army he came back here and opened up a hardware store. Probably no one in the town expected him to return at all much less open up a hardware store.

The enterprise didn't flourish and it didn't fail. It merely survived and with it its owner, his wife and three sons. He was enormously proud of this fact: that the store had merely survived. He didn't like the idea that expansion was the requirement of survival-in business or anything. "If it had gone in either direction, up or down," he said of the store, "I wouldn't be here."

He married, loved his wife, sired three boys, one of whom was killed riding a bicycle. And one day when the two remaining boys were old enough to take care of themselves, he left home, store, wife and boys, the town and his friends, and came here to sit in the wicker chair under the olive trees.

Some said, "How can a man reject his family like that?" but he wasn't rejecting his family. Sarah stood by him for a long time, the boys for longer. They understood him, I think. When she finally left him legally, neither begrudged the other for what had happened. 
He wasn't antisocial either. He welcomed my coming as a host welcomes an uninvited guest who is welcome anyway. When we had other guests he welcomed them all, in his way, as host under the olive trees. He was a kindly man. He was interested in other people. However they had to accept him and his way as he had set it up, and if they couldn't or wouldn't, they had only to go their own.

He didn't talk much because it wasn't in his nature to talk much. People misunderstood that sometimes. Most of us think we have to talk to prove our interest or our friendship.

People said he was a troubled man and he was. All men are troubled.

I'd be tempted to say that our best days were the first ones. My learning period, or unlearning as he put it. It's astonishing to find out that the less you want the less you want. Few do. Find it out, I mean. Hoboes maybe, and men who sit under olive trees. Our physical needs took maybe half an hour a day. We slept a scant seven hours, less in the shorter nights, although there were long stretches when with my eyes open I saw the familiar shapes, the trees climbing up toward where the first houses begin, without seeing them at all. Half-sleep, I guess you'd call it. At moments like these color itself ceases and the air gets fogged without there being a cloud or even a patch of mist in the valley bottom and time seems to stop and wait alongside you. Until something breaks the spell-a bird in sudden flight, an automobile slowing for the bridge-and the trees come back into focus and you stir and wake up.

There is always time, a cornucopia of it. Time to talk, to wonder, contemplate, to dream. I think it's time that frightens most people.

We talked of everything and nothing. He had a vast knowledge. He knew more of nature than any man I ever met. It took me the longest time to find out where he'd gotten it. He taught me the names of the birds. He taught me to predict weather just from qualities in the air. I learned about the sun and the moon, stars, trees and plants, the seasons, as people first did, from observation and living in their dompany. In the beginning I seldom even saw the birds he pointed out in the branches, but I came to know not only where and what they were but when they would leave and when return.

We talked about economics, yes, and politics and civilization and the glories and failures of it, but we were neither of us philosophers, though he was later called one. He taught me chess. I can't say who was finally master and who weaker, because we often left the games unfinished. We played less to win than to get an interesting position on the board.

We had our difficulties too, I wouldn't deny it. His face-that look of insupportable tension-didn't altogether belie the man behind it. Calm as he was, he too felt the restlessness which drives men. There were days when he paced back and forth under the trees or by the stream and cursed himself, the world, life, for being as they were. On two occasions he left.

Both times when I awoke in the morning he was gone.

I never learned where he went that first day and he never mentioned it. It felt as if a piece of myself had fallen off. But I didn't go after him because I sensed he would be back, and I was right.

By the second time he was already famous and his picture appeared in the 
paper. He'd gone to the sea. The surf showed in the background. His back was to the camera and the caption read: "No Man is Alone."

At which we both laughed, one of his few wholehearted laughs though his sense of humor was keen.

I asked him, "How was the sea? Still there?"

"Yes, still there," he said, "still angry at the land and hitting it."

I said, "A man could sit by the sea a long time too," for by then I'd begun to fear we would have to leave the valley.

"Men do," he said, "but there aren't any olive trees."

One reporter, you see, started it all. McAdams was his name. One young reporter on a local paper who'd nothing better to do, I suppose, than hunt down odd stories which might or might not make his fame and fortune. Ours didn't, of course, because others took it from him.

After he'd gone that day, Mr. Charles said, "Well, that's the end of that."

"The end of what?" I asked.

"The end of status quo, my friend."

I thought he was exaggerating. He said, "You'll see. You and I are the world's best press agents."

The headline was "Men Who Do Nothing." McAdams had described our life simply and accurately, with none of the pro or con colors of later stories. To everyone's amazement except Mr. Charles', it attracted more mail than any story in the paper's history, and for weeks two columns of letters ran side by side, one headed "Let Them Stay" and the other "Make Them Get Out."

Overnight we became a cause.

People started coming out to see the two strange men who sat under the olive trees, not only reporters but people too. God knows what they expected. They shouted at us sometimes, the pros and the cons as Mr. Charles called them.

The cons labeled us everything under the sun from "lazy no-good bastards" to "radical commie faggots." Some just shook their fists. I remember one pro shouting, "You stay right where you are, boys. We'll show 'em!"

After a while they started coming down the slopes, mostly the pros, and people began bringing and sending us things. A local dealer sent out twelve gallons of ice cream, which was good for us because the day was hot and we had it to offer our guests, and good for him because he got his name in the paper. Later we got clothes and blankets and books, most of which we didn't need, and even an electric rotisserie which we gave to one of the ladies on the hill, even a tent.

I forget what happened to the tent. Maybe it was stolen. Some things were.

An incredible amount of food.

And mail. Bagfuls of it eventually. That picture got into the papers too, of the mailman lugging a huge sack of letters down the slope. One was addressed to "Them Two Fellers in the Valley." I read a lot of them, Mr. Charles just a few. Some of the cons were unprintable, some of the pros touching. People identified us with all kinds of causes, protests, sects. We even got our share of mail-order circulars: book clubs, arthritis cures and so on.

No bills though.

It grieved me that we couldn't answer it, some of it anyway. Not Mr. Charles. 
He said the people who'd written had already answered themselves and that both were good things: the writing and the answering. Call it a meanness in him if you want to. I thought so, a little. But what he was getting at was that people had their preconceived notions about us and that nothing we did or said would change their notions, and that it was good for notions to be aired.

He didn't want to change the world, that was the point.

The cons gave us less grief than you'd have thought. We heard some night prowlers, kids we guessed. "Probably trying to catch us in the act," Mr. Charles said. But we never actually saw them. Mostly it was the fist-shakers and the poison-penners. And the evicters.

The first real news we had of the evicters was when Mr. Bagbee came to see us. It turned out he was the man who owned the land, all of it from the bridge on down to the last hills which overlooked the sea. "A lovely piece of property," Mr. Bagbee called it and so it was. He also owned a chain of drugstores.

"I've never done anything with it," he said, "and it's not worth much now. People want the view these days and you can't see the sea from down here. Some day it'll be worth something, I expect.

"But they're after me to sell. Either that or chase you off. Now don't get me wrong, Mr. Charles, I've nothing against you. As far as I'm concerned you can stay as long as you like. I've never used the land and someone may as well. But I've been threatened. There's talk of reprisals, boycotts."

"You do whatever you think best," Mr. Charles told him. "We'll get out if we have to, or stay if you let us."

Maybe all Mr. Bagbee wanted was some company, because he stuck to his guns. There were pickets outside his store for a while but maybe the pickets attracted customers. Anyway the evicters gave up in the end.

Once we saw a list of their names on some petition. Neither of us knew a one.

But if I thought we might have to leave then, I really thought so when, like they say, our story "went national." Not because of anything legal. We weren't breaking the law. There was trouble about the traffic and people parking just anywhere in order to see us and all those who came to stay awhile and the television trucks and all, but as Mr. Charles said, "The police'll work it out because the town's making money."

It was because of Mr. Charles himself. From the beginning he was the center of attention and the target when there was a target. This was only as it should be. $\mathrm{He}$ was the more striking physically and the more interesting intellectually. He had been here first. In the beginning I was his guest and then his pupil and in many ways these first relationships held. Then too, he said little, which made it possible for him to be cast in any number of roles.

He was good copy.

For instance an interviewer asked him, "What are you waiting for, Mr. Charles?"

And he answered, "We're just waiting, I guess."

Which, true enough, could be taken several ways. The reporter in question decided we were waiting for God. 
Another one asked, "What would become of the world if everyone did what you two are doing?"

"It'd starve," Mr. Charles said.

"Yet you stay here doing nothing?"

"Yes," Mr. Charles agreed. "It's not a life I can recommend to everyone."

A lot of pictures appeared and a lot of articles, a lot of them nonsense. One big magazine sent out a psychologist who wrote a long study about antisocial behavior. The psychologist had asked Mr. Charles if he thought we were antisocial.

"No, I don't think so," Mr. Charles had said.

"But isn't the mere fact of your living as you do a signal of it?"

Mr. Charles had merely circled his arm to show all the people around our chairs and under the olive trees and on the slopes and the cars jamming the road.

The psychologist still wrote a long study about antisocial behavior.

I thought though that it was all getting to him. Not the nonsense so much but the people, the fuss. He wasn't ever gregarious but he'd become even more quiet. He sat for longer stretches without moving, the figure I still thought of as big bigger than ever in that wicker chair, surrounded by a forest of angularities. I was afraid he'd go, I guess, with or without me.

It shows how little I understood him sometimes.

One night when a television crew had packed up and gone and we were alone finally among the trees and also all the debris people leave behind, he told me not to worry.

"I know what's on your mind," he said, "but it won't last much longer, I think. There's no real story here and they'll find it out sooner or later. Not even the best press agents in the world can sell an empty box.

"Besides," he said, "it's pretty interesting, don't you think so? Maybe everyone has a touch of the ham in him. I do. You too possibly. But how many get the chance to go on stage?

"Besides," he said, "the moon is new. How many men get to sit under a tree and watch the moon when it's new? A man who can watch the new moon has no need to hurry."

Which was his way of teasing because the moon wasn't new that night.

He was right though. The papers and magazines and TV got their one big story and then there wasn't much left. We'd still see them from time to time and a few "they're still there" stories ran, but they had better things to do, I guess. Some new human-interest fad had come along. I forget what it was.

Not that we were left alone. If anything we had more visitors after the professionals left. "Publicity-lash," you could call it. They came and gawked and took pictures-God knows how many pictures were taken of Mr. Charles with somebody's wife or husband in the background-and went their way. Those who were looking for a message stayed longer and went away more disappointed.

Of those who stayed, Mr. Charles liked the young people best. There were a lot of them in the summer. Maybe they'd nothing better to do and at least, you could say, we kept them off the streets. They camped in the valley and we shared what we had with them. In the evenings they played their guitars and sang in 
circles and from our chairs under the tree we could hear the music even though we couldn't see the faces.

And of course it was charged that they were turning the landscape into a brothel.

They liked Mr. Charles, I think, because he listened to them. Usually they've no one who really listens except themselves, which is too incestuous, but $\mathrm{Mr}$. Charles really listened and he cared about what they said.

What more did they expect of him? A slogan? An endorsement? Leadership? Probably they didn't know themselves. He sympathized with the pacifists, with free love and free drugs, with equal rights, with all their causes, even the more frivolous ones. Beyond that he could only listen, which he did.

What none of them grasped was that our life under the trees wasn't a protest. We weren't saying "No." We had only elected to stand-or sit-outside the mainstream of life. People or circumstances might force us to give it up, but meanwhile we were sitting in the chairs by choice. As he'd said, it wasn't a life to be recommended to everyone. It was only the one we'd adopted.

When one of the young men accused us of being "disengaged," Mr. Charles said, "Yes, I guess we're disengaged," and the young man looked ashamed and exclaimed, "But man, how can you be?"

Mr. Charles stared back at him and said nothing. I guess there wasn't any answer.

With the end of summer the young drifted away as they'd come, like hitchhiking Indians. School was starting again and a little nip could be felt in the air after the sun went down. Then too, Mr. Charles hadn't turned out to be the oracle after all.

One group outlasted the young, though many of them were young too. It took them longer to be convinced.

I'm referring to the Witnesses. To borrow, they came early and stayed late. A persistent bunch of people, Witnesses, as we found out.

Witnesses believe in Armageddon. So do a great many others but Witnesses really believe in it, as a physical event that's going to happen. Maybe their success can be explained in these terms: a man who can be made to believe that Armageddon's coming any day now is going to want to save himself if he can, and the person who convinced him is likely the first one he'll turn to for help.

Needless to say Mr. Charles and I didn't so believe. As he said to me after one particularly long siege, “There'll be men sitting under olive trees after a dozen of their Armageddons have come and gone. There always have been. Even Noah managed to sit under a tree before he died. If I told them that, though, it'd break their hearts."

Maybe they thought we were Messiahs. Or that since we'd admitted to waiting, we might secretly be waiting for Armageddon and they'd better wait with us. Besides, since we seemed to attract other non-Witnesses, our valley was fertile territory for them.

It was embarrassing sometimes. People would come to see Mr. Charles and before they even got to him half a dozen men and women would try to sell them Awake or The Watchtower. 
He wasn't a saint maybe, but he had the patience of one.

In the end then we were left with the Witnesses, two men sitting in wicker chairs under an olive tree surrounded by a wide-eyed lot of convincers, converters, advocates, proselytizers-missionaries, I suppose. No worse or better a lot at that.

And the Witnesses were left with us. When finally they saw that there wasn't anyone left to convert except themselves and two men who were either already saved or never would be, and that therefore they were sinning against their own missionary precept, they too were on their way. Unlike the flotsam young, they went in an army.

So we were alone, two men a few seasons older sitting under a tree, as he had assured me we would be and as I'd never quite believed.

I suppose most of the people had come in the hope of finding something, and they'd left when they didn't. There wasn't anything for them to find really, just a pretty valley with some trees and a dried-up stream.

Maybe Mr. Charles missed the company at that. His large head was directed more than ever across the streambed toward the slopes, as if he was looking at something he couldn't quite make out. His grooves had deepened some and then there was water in the stream again. He left to see the sea and came back for the last time but one.

His talk now, what there was of it, was full of his boyhood. His biggest pleasure as a shaver, he said, had been to sit in or under a tree and watch the world, as much of it as passed in front of his eyes. He supposed he was missing a lot that way, he knew he was, but there was enough, more than enough, already an overflow. Then life had set about stuffing him up to the brim and then stamping down on the stuffing to make room for more, the way a homeowner stomps his garbage in a pail. He'd reached a point of being so stuffed, he said, that his senses no longer worked. His ears got dull, his eyes glassy, his nose and tongue too confused by all the smells and tastes to pick out any one. His mind stopped too. He'd reached what he called with a smile the stage of maturity. One more forkful and he'd have had to throw up.

So little by little, he said, he'd started to empty himself.

When he spoke about such things, I imagined how the grooves in his face were evidence of the emptying, how one time they must've been filled out and now the skin was falling back on the emptied space, and that what he was after was to get to, or regain, a vision so acute that he could pick out every last detail on the one facing slope down to the last immobile ant.

"Trouble is," he said to me, "once a man is stuffed he can never quite rid himself of the gristle."

The grooves went on deepening and time slowed again and almost stopped.

He wasn't old by today's standards. His health so far as anyone could tell was excellent. Yet he died. In one night he died. When I awoke in the morning he was dead in his chair.

A doctor came, police too. His ex-wife and sons came. They took his corpse off and put it in a cemetery.

The evening before he died he told me how he'd happened to come to the valley. He'd never mentioned it. Maybe he thought it was the last thing I needed 
to know. Maybe he was emptying little by little and feeling the emptying and knew as he talked to me that he would be drained all the way out before the sun came up again.

"We're different men with different histories," he said to me, "but maybe not so different after all. I used to cross our bridge now and then and I used to see a man sicung under this tree. I thought he might be fishing but he never held a rod and the stream is mostly dry. One day I thought I'd climb down and sit next to him for a while..."

As he went on, chuckling because he knew-had always known-that my experience had been much the same as his, I understood why he'd had that air of acceptance about him in the beginning, why he'd seemed to expect me, as if he'd known I, or someone like me, would be along one day or another as he'd once come along for his predecessor. As if it had always been like that.

The idea made me shiver a little. I asked how the other man had come to the valley.

"I don't know." He was looking straight ahead. "He died before he could tell me."

"But how did he die?" I asked.

"I don't know. He was old enough. Or empty enough."

"He taught me all I know about nature," Mr. Charles confessed, "and chess. He always wanted to beat me, usually did."

They'd sat together undisturbed-“He lacked your touch for publicity," Mr. Charles said-and then Mr. Charles had had to sit alone for a time as I did more recently, and then I came down the slope on the other side of the stream, as you did.

I don't know why Mr. Charles died either. The doctor may've had an explanation, the police another, his wife and sons another. I think he was just empty.

So there is a chain of sorts, you see.

The trees will outlive us all.

I wanted you to know about it. 